Article

\title{
BIM-VE-Based Optimization of Green Building Envelope from the Perspective of both Energy Saving and Life Cycle Cost
}

\author{
Zhenmin Yuan ${ }^{1,2}$, Jianliang Zhou ${ }^{1,2, *}$, Yaning Qiao ${ }^{1,2}$, Yadi Zhang ${ }^{3}$, Dandan Liu ${ }^{1}$ and Hui Zhu ${ }^{1}$ \\ 1 School of Mechanics and Civil Engineering, China University of Mining and Technology, \\ Xuzhou 221116, China; tbh171@cumt.edu.cn (Z.Y.); yaning.qiao@cumt.edu.cn (Y.Q.); \\ ldd_2019@163.com (D.L.); 15706298215@163.com (H.Z.) \\ 2 State Key Laboratory for Geomechanics and Deep Underground Engineering, China University of Mining \\ and Technology, Xuzhou 221116, China \\ 3 School of Civil Engineering, Harbin Institute of Technology, Harbin 150001, China; sdzyd100@163.com \\ * Correspondence: zhoujianliang@cumt.edu.cn
}

Received: 1 September 2020; Accepted: 22 September 2020; Published: 23 September 2020

\begin{abstract}
In the context of the increasingly severe energy crisis and global warming, green buildings and their energy-saving issues are being paid more attention in the world. Since envelope optimization can significantly reduce the energy consumption of green buildings, value engineering (VE) technology and building information modeling (BIM) technology are used to optimize the envelope of green buildings, which takes into account both energy saving and life cycle cost. The theoretical framework of optimization for green building envelope based on BIM-VE is proposed, including a BIM model for architecture, a life cycle cost analysis model, energy-saving analysis model, and a value analysis model. In the life-cycle cost model, a mathematical formula for the life-cycle cost is established, and BIM technology is used to generate a bill of quantity. In the energy-saving analysis model, a mathematical formula for energy saving is established, and BIM technology is used for the building energy simulation. In the scheme decision-making sub-model, VE technology integrating life cycle cost with energy saving is used to assess the envelope schemes and select the optimal one. A prefabricated project case is used to simulate and test the established methodology. The important results show that the 16 envelope schemes make the 16 corresponding designed buildings meet the green building evaluation standards, and the optimal envelope scheme is the "energy-saving and anti-theft door + exterior window $2+$ floor $1+$ exterior wall $1+$ inner shear wall + inner partition wall 2 + planted roof" with the value $10.80 \times 10^{-2} \mathrm{MW} \cdot \mathrm{h} / \mathrm{ten}$ thousand yuan. A significant finding is that the value generally rises with the increase of energy-saving rate while the life cycle cost is irregular with the increase of energy-saving rate. Compared with previous efforts in the literature, this study introduces VE technology into architectural design to further expand the current boundary of building energy-saving theory. The findings and suggestions will provide a valuable reference and guidance for the architectural design industry to optimize the envelope of green buildings from the perspective of both energy saving and life cycle cost.
\end{abstract}

Keywords: green building envelope; energy saving; life cycle cost; VE; BIM

\section{Introduction}

\subsection{Research Background and Question}

Excessive energy consumption leads to global warming, which further exacerbates the energy crisis. The global warming and energy crisis have become two major problems encountered by 
human beings in the 21st century. Due to the energy crisis and global warming, human beings are under increasing pressure to pay more attention to energy conservation and emission reduction [1]. The energy consumed by buildings has a dominant share in the total social energy consumption [2,3]. In America, residential and commercial buildings consume $40 \%$ of total energy consumption, while in Europe, they account for $40 \%$ of total energy consumption [4]. In China, the building sector contributes about $20 \%$ of total energy consumption, which is the second largest energy consumption sector [5]. Compared with conventional buildings, green buildings pay more attention to energy-saving design, which helps to encourage people's energy-saving behaviors [6]. Hence, green buildings and their energy conservation is becoming popular all over the world [7]. Since the thermal protection in a building is the most effective energy-saving approach [8], the design and optimization of an envelope become critical to the energy saving of green buildings.

\subsection{Question-Related Literature Analysis}

Various definitions of green buildings have been developed so far. The definition from World Green Building Council (WorldGBC) is "A green building is a building that, in its design, construction or operation, reduces or eliminates negative impacts, and can create positive impacts, on our climate and natural environment" [9]. The term "energy" is particularly valued among its many characteristics. Other organizations have similar definitions of green buildings, such as United States Environmental Protection Agency (EPA), United Kingdom and European Union [9]. Green building evaluation systems have also been established, such as Green Mark, Green Star, LEED, BREEAM, and HK-BEAM [10]. In June 2006, China issued the first national green building evaluation standard: "Evaluation Standard for Green Building (ESGB)" (GB/T50378-2006). Building energy-saving theory has always been highly valued. Many scholars have explored the energy-saving performance of green buildings, such as Huang et al. [11], Raji et al. [12], and Zhang et al. [13]. The application of suitable green building products plays an important role in facilitating energy-saving building [14]. Obviously, given the high consistency and compatibility between energy saving and green buildings, it is necessary to investigate the feasibility of integrating energy-saving theory with green buildings.

Building energy-saving theory refers to the knowledge of technologies, methods, policies, regulations, and contracts related to energy conservation in the life cycle of buildings. Energy-saving technology among them has always been a very popular research topic. Energy-saving technology for green buildings is divided into three categories: Passive technologies, HVAC (heating, ventilation, and air-conditioning)-related technologies, and renewable energy-related technologies [15]. Passive technologies are a kind of common and primary technology in building design, which reduces the energy consumption of HVAC by reasonably setting the building orientation, building shading, envelope's thermal insulation, and natural ventilation. The research related to passive energy saving is summarized as follows: The impact of wall design on energy saving [16-20], the impact of roof design on energy saving [21-24], the impact of vertical greenery systems on energy saving [25-29], the impact of envelope configurations on energy saving [30-33], and the impact of envelope and other systems on energy saving [34]. However, these studies only consider the energy conservation but ignore the life cycle cost, which is a very important evaluation index for green building envelope design. Few scholars comprehensively study the design of building envelope from energy saving, cost and even more aspects, such as Lu et al. [35], Xie et al. [36], Chiradeja and Ngaopitakkul [37], and Iwaro et al. [38]. However, these studies do not unify the energy-saving goal and cost goal. The final architectural design scheme can only be obtained from the intersection of the scheme set corresponding to each goal. If energy saving and life cycle cost cannot be considered in the design of green building envelopes, the following undesirable phenomena may occur in reality: On the one hand, the high energy saving corresponding to the high cost makes it difficult to promote the design of green building envelopes in reality; on the other hand, the low energy saving corresponding to the low cost makes the design of green building envelopes too common and uncompetitive. These undesirable phenomena will affect the sustainability of green buildings in terms of energy saving, and make market-driven 
green buildings fail to develop well. Hence, it is of necessity to optimize green building envelope from the perspective of both energy saving and life cycle cost.

\subsection{Research Aim and Significance}

Green buildings have received more global attention, but there seems to be a conflict between the energy saving and economy of green buildings. Hence, it is vital to search for a balance between the two. This study aims to adopt BIM and VE to optimize green building envelope from the perspective of both life cycle cost and energy saving, which makes green buildings not only energy-saving but also economical. Since energy saving is a common goal of the whole society, this study will increase the contribution share of green buildings in social energy saving. Besides, it will further expand the current boundary of building energy-saving theory, and provide a valuable reference and guidance for architectural design departments in terms of the green building envelope design. Other sections of this study are structured as follows: Firstly, BIM is combined with VE to establish an optimization method for green building envelopes, and then the principle of this method is described in detail. Secondly, a prefabricated project case with green building properties is used to simulate and test this method, and then the obtained results are analyzed and discussed in depth. Finally, conclusions and future work are summarized.

\section{Research Methodology}

\subsection{Framework Design of Research Methodology}

Compared with ordinary buildings, energy saving is an important objective pursued by green buildings. The internal and external environments of green buildings are separated by building envelopes. The internal environment is adjustable while the external environment is non-adjustable. The adjustment and control of internal environment need to be realized by energy consumption. However, excessive energy consumption will cause serious damage to the external environment (namely the natural environment). The optimization of building envelopes is conducive to energy saving. A green building envelope consists of various building components, such as roofs, doors, windows, walls, and floors [39]. Due to the different materials, each component is subdivided into multiple types. Hence, the optimization of building envelopes means that architectural designers select the required types of components to form an optimal envelope.

However, the optimization of building envelopes should not only consider the energy-saving goal, but also consider the life cycle cost goal. Value engineering (VE), also known as value analysis, can realize the unification of function (e.g., energy saving) and cost [40]. Building information modelling (BIM) has gradually extended other functions on the basis of the initial three-dimensional modelling, such as energy simulation analysis and cost calculation [41]. Hence, VE is combined with BIM to establish an optimization method for green building envelopes, as shown in Figure 1. This method consists of four main models, namely a BIM model for architecture, a life cycle cost analysis model, energy-saving analysis model, and a value analysis model. There is a rigorous logical relationship between these four models. Since the BIM model for architecture contains rich basic data, it is the basis of the other three models. The $m$ envelope schemes generated with the aid of this BIM model establish a connection between the life cycle cost analysis model and the energy-saving analysis model. The output of the second and third models is used as the input of the fourth model (namely the value analysis model). Various BIM Technology, VE technology and calculation formulas are integrated into this method for achieving the effect of " $1+1>2$ ". 


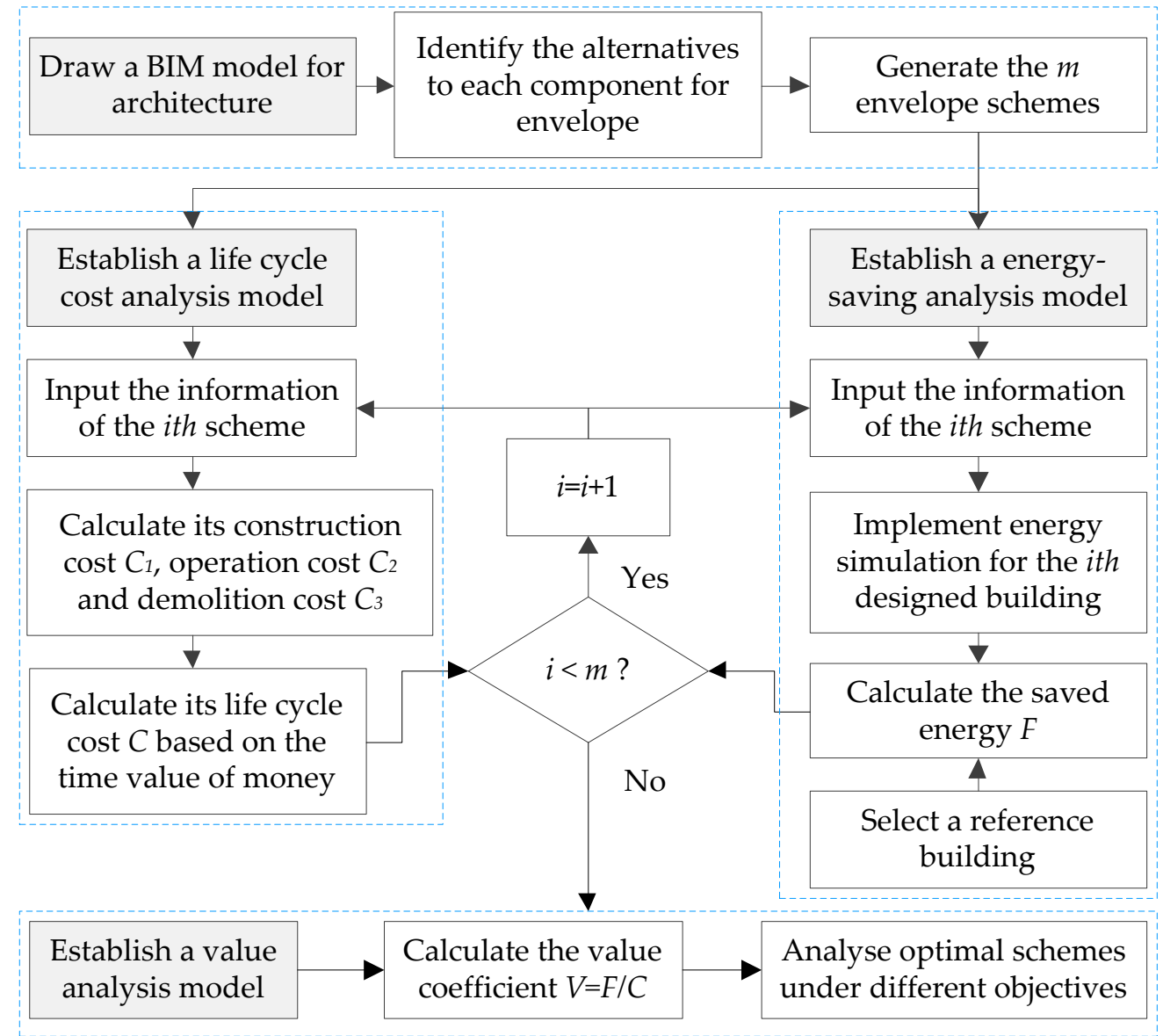

Figure 1. Optimization method for green building envelopes based on building information modelling-value engineering (BIM-VE).

Value engineering (VE) is a decision-making technology via measuring the ratio between the function and cost of an entity, and has been used in the construction industry since the 1980s [42]. For green buildings, the value of an envelope scheme needs to consider both economic and functional indicators. Hence, the value analysis model regarding green building enclosure is shown in Formula (1). $V$ represents the value of an envelope scheme; $F$ represents the function of an envelope scheme, such as the energy saving; $C$ represents the life cycle cost of an envelope scheme. The optimal envelope scheme is the scheme corresponding to the maximum value $V$ max.

$$
V=\frac{F}{C}
$$

\subsection{Life Cycle Cost Analysis Model for Green Building Envelope}

Although the life cycle of a green building includes all stages from the initial planning to the final demolition [43], different schemes of a building envelope mainly affect its construction cost, operation cost, and demolition cost. Hence, the life cycle cost analysis model for green building envelope is shown in Formula (2). Considering the time value of money, the present-value interest factor of annuity (PVIFA) and present-value interest factor (PVIF) are adopted. $C$ represents the life cycle cost of a green building envelope; $C_{1}$ represents the construction cost of a green building envelope; $C_{2}$ represents the annual operation cost of a green building envelope; $C_{3}$ represents the demolition cost 
of a green building envelope; $i$ represents the discount rate; $n$ represents the design working life of a green building envelope.

$$
C=C_{1}+C_{2} \times\left(\frac{1}{i}-\frac{1}{i(1+i)^{n}}\right)+C_{3} \times \frac{1}{(1+i)^{n}}
$$

BIM technology (e.g., BIM cost software) makes full use of the BIM model for architecture to generate a bill of quantities, and then combines with project quotas to calculate the costs. This replaces a lot of heavy manual work, and improves the accuracy of quantity. Hence, the construction cost of a green building envelope is suggested to be calculated by BIM cost software and project quotas. The annual operation cost of a green building envelope is suggested to be calculated according to the annual power consumption of HAVC system and the local electricity price. To simplify the calculation, the demolition cost of a green building envelope takes a certain percentage of the construction cost.

\subsection{Energy-Saving Analysis Model for Green Building Envelope}

The thermal insulation performance for green buildings is mainly determined by their envelopes, which will affect the effect of energy saving. A component of building envelopes generally has multiple types, and each type of component has its specific heat transfer coefficient. Since the internal environment of buildings is actively adjusted through HVAC system (including heating system and cooling system), the energy saving of green buildings is represented by the energy saving of the HVAC system. Different calculation methods of the annual energy consumption for buildings have been provided by some standards and scholars, such as Monstvilas et al. [44], Zhang et al. [45], and Jin et al. [46]. Common BIM technology is often combined with some standards to calculate the energy consumption of buildings. According to the "Standard for Green Performance Calculation of Civil Engineering" (JGJ/T449-2018), the annual energy consumption of heating and cooling for a building is calculated according to Formulas (3) and (4), respectively. $E_{\mathrm{h}}$ represents the annual heating energy consumption of a building (KW·h); $E_{\mathrm{c}}$ represents the annual cooling energy consumption of a building $(K W \cdot h) ; Q_{h}$ represents the cumulative annual heating consumption of a building $(K W \cdot h) ; Q_{c}$ represents the annual cumulative cooling consumption of a building $(K W \cdot h) ; \theta_{\mathrm{h}}$ represents the conversion weight of comprehensive efficiency for heating system; $\theta_{\mathrm{c}}$ represents the conversion weight of comprehensive efficiency for cooling system.

$$
\begin{gathered}
E_{\mathrm{h}}=\frac{Q_{\mathrm{h}}}{\theta_{\mathrm{h}}} \\
E_{\mathrm{c}}=\frac{Q_{\mathrm{c}}}{\theta_{\mathrm{c}}}
\end{gathered}
$$

Hence, the energy-saving analysis model for green building envelope is shown in Formula (4). This model involves two green buildings: One is regarded as a reference building, and the other is regarded as a designed building. The designed building and the reference building are the same except for the envelope. The heat transfer coefficient of each component for the reference building takes the limit value of the selected standard. The designed building will be changed according to different envelope schemes. $F$ represents the energy saving of the designed building corresponding to a certain envelope scheme, as shown in Formula (5). $E_{\mathrm{dh}}$ and $E_{\mathrm{dc}}$ respectively represent the annual heating and cooling energy consumption of the designed building. $E_{\mathrm{rh}}$ and $E_{\mathrm{rc}}$ respectively represent the annual heating and cooling energy consumption of the referenced building. In order to further clarify the logical relationship and meaning between the parameters in the above formulas, the Table A1 of Appendix A summarizes these parameters in a certain order logic.

$$
F=E_{\mathrm{dh}}+E_{\mathrm{dc}}-\left(E_{\mathrm{rh}}+E_{\mathrm{rc}}\right)
$$

BIM technology (e.g., BIM energy-saving analysis software) with built-in standards is used for building energy simulation analysis on the basis of the BIM model for architecture. Besides, 
BIM technology defaults to the calculation method of the heat transfer coefficient for the envelope components based on the built-in standards. Hence, the adoption of BIM technology replaces a lot of heavy manual work, and improves the efficiency of calculation.

\section{Envelope Optimization of a Project Case}

\subsection{Basic Information Regarding the Project Case}

Due to the one-off characteristic of projects and the potential risk of new methods, it is unrealistic to apply newly established methods to projects immediately. However, these new methods have to be tested urgently so as to realize their practical value as soon as possible. Case studies combined with simulation technology are an effective approach to simulate and test a newly established methodology. These cases refer to the projects that have happened in the past. With the help of virtual simulation technology, the construction process of a historical project can be reoccurred or recreated to test the established methodology at a minimum cost. Some authors of this study have ever been involved in the planning and design of a building project. Its BIM model and basic information are shown in Figure 2 and Table 1, respectively. The Koppen climate classification is an international climate classification, which is adopted in many studies [47-50]. In the Koppen climate classification [51,52], Nanjing corresponds to the Cfa type climate, which means the hot summer and cold winter. Its envelope consists of the following main components: Doors, roofs, interior walls, external walls, windows, and floors.

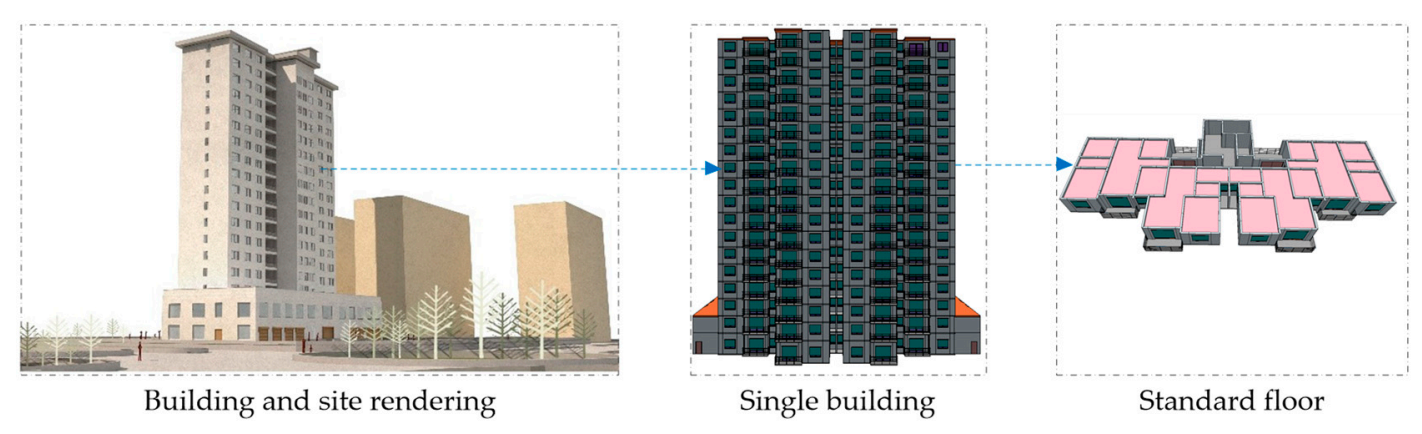

Figure 2. BIM model of the project case.

Table 1. Basic information of the project case.

\begin{tabular}{llll}
\hline \multicolumn{1}{c}{ Items } & \multicolumn{1}{c}{ Contents } & \multicolumn{1}{c}{ Items } & \multicolumn{1}{c}{ Contents } \\
\hline Building location & Nanjing city & Building layers & 18 floors above ground \\
Climate zoning & Cfa type climate & Building height & $53.6 \mathrm{~m}$ \\
Building orientation & South & Gross floor area & $10,143.38 \mathrm{~m}^{2}$ \\
Building use & Residence & Building durability & 50 years \\
Building category & Class II high-rise building & Seismic precautionary intensity & 8 degrees \\
Building structure type & Prefabricated shear wall structure & Fireproof endurance rating & 1 level \\
Building energy-saving form & Passive energy saving & - & - \\
\hline
\end{tabular}

The bill of quantity for the building envelope is calculated by BIM cost software. In order to be consistent with the unit in the quota (or standard), the unit of quantity for the building envelope is changed from volume to area, as shown in Table 2. 
Table 2. Bill of quantity for the building envelope.

\begin{tabular}{lc}
\hline Items Regarding the Area of Envelope & Quantities $\mathbf{( m}^{\mathbf{2}} \mathbf{)}$ \\
\hline Door area & 151.20 \\
Exterior window area & 1386.24 \\
Floor area & 6829.17 \\
Internal surface area of exterior walls & 5441.11 \\
External surface area of exterior walls & 6539.52 \\
Double-sided area of interior shear walls & 5909.23 \\
Interior partition wall area & 4390.32 \\
Roof area & 1153.94 \\
\hline
\end{tabular}

\subsection{Types of Each Component for the Building Envelope}

This building project sets many criteria for judging whether the design is successful, one of which is to achieve green building design in terms of energy saving. Since thermal protection is the most effective energy-saving way, the envelope of this building project needs to be optimized on the basis of meeting other design requirements/criteria. The "Design standard for energy efficiency of residential buildings in severe cold and cold zones" (JGJ 26-2010) was still valid when some authors of this study participated in the building project. According to the limit value of this design standard, thermal parameters of envelope for a reference building are set. Table 3 indicates the thermal parameters of main components for reference building envelope. The heat transfer coefficient of partition walls is calculated based on the weighted area of interior partition walls and interior shear walls.

Table 3. Thermal parameters of main components for reference building envelope.

\begin{tabular}{lccc}
\hline \multicolumn{1}{c}{ Thermal Parameters } & Units & Numerical Values \\
\hline Heat transfer coefficient of roofs & & $\mathrm{W} /\left(\mathrm{m}^{2} \cdot \mathrm{K}\right)$ & 1.00 \\
$\begin{array}{l}\text { Heat transfer coefficient of exterior walls }\left(^{*}\right) \\
\text { Heat transfer coefficient of partition walls (e.g., interior }\end{array}$ & $\mathrm{W} /\left(\mathrm{m}^{2} \cdot \mathrm{K}\right)$ & 1.50 \\
$\begin{array}{l}\text { partition walls and interior shear walls) } \\
\text { Heat transfer coefficient of floors }\end{array}$ & $\mathrm{W} /\left(\mathrm{m}^{2} \cdot \mathrm{K}\right)$ & 2.00 \\
Heat transfer coefficient of doors & $\mathrm{W} /\left(\mathrm{m}^{2} \cdot \mathrm{K}\right)$ & 2.00 \\
Heat transfer coefficient of exterior & East & $\mathrm{W} /\left(\mathrm{m}^{2} \cdot \mathrm{K}\right)$ & 3.00 \\
windows (including transparent & South & $\mathrm{W} /\left(\mathrm{m}^{2} \cdot \mathrm{K}\right)$ & Normal window: 4.70 \\
curtain wall) & West & $\mathrm{W} /\left(\mathrm{m}^{2} \cdot \mathrm{K}\right)$ & Normal window: 3.20 \\
& North & $\mathrm{W} /\left(\mathrm{m}^{2} \cdot \mathrm{K}\right)$ & Normal window: 4.70 \\
& & & Normal window: 4.70 \\
\hline
\end{tabular}

Note: $\left({ }^{*}\right)$ is the weighted average heat transfer coefficient of all exterior walls.

Compared with the reference building, a designed building serves as an experimental object. The experimental principle is to observe the corresponding experimental results by changing the thermal parameters of envelope. Except for the thermal parameters of envelope, other indicators (e.g., shape coefficient) of the designed building and the reference building are the same. The experimental results are compared with this reference building. BIM models corresponding to building envelope components are shown in Table 4. According to the actual situation of the project and the available materials, there are two options for interior partition walls, exterior walls, exterior windows and floors while there is only one option for doors, roofs and interior shear wall. The doors are energy-saving anti-theft doors, and the roofs are planted roofs. PKPM-Energy, a kind of energy analysis software, is used for the energy simulation of the building. The detailed material information, thermal parameters and comprehensive unit price of building envelope components are shown in the Table A2 of Appendix A. 
Table 4. BIM models corresponding to building envelope components.

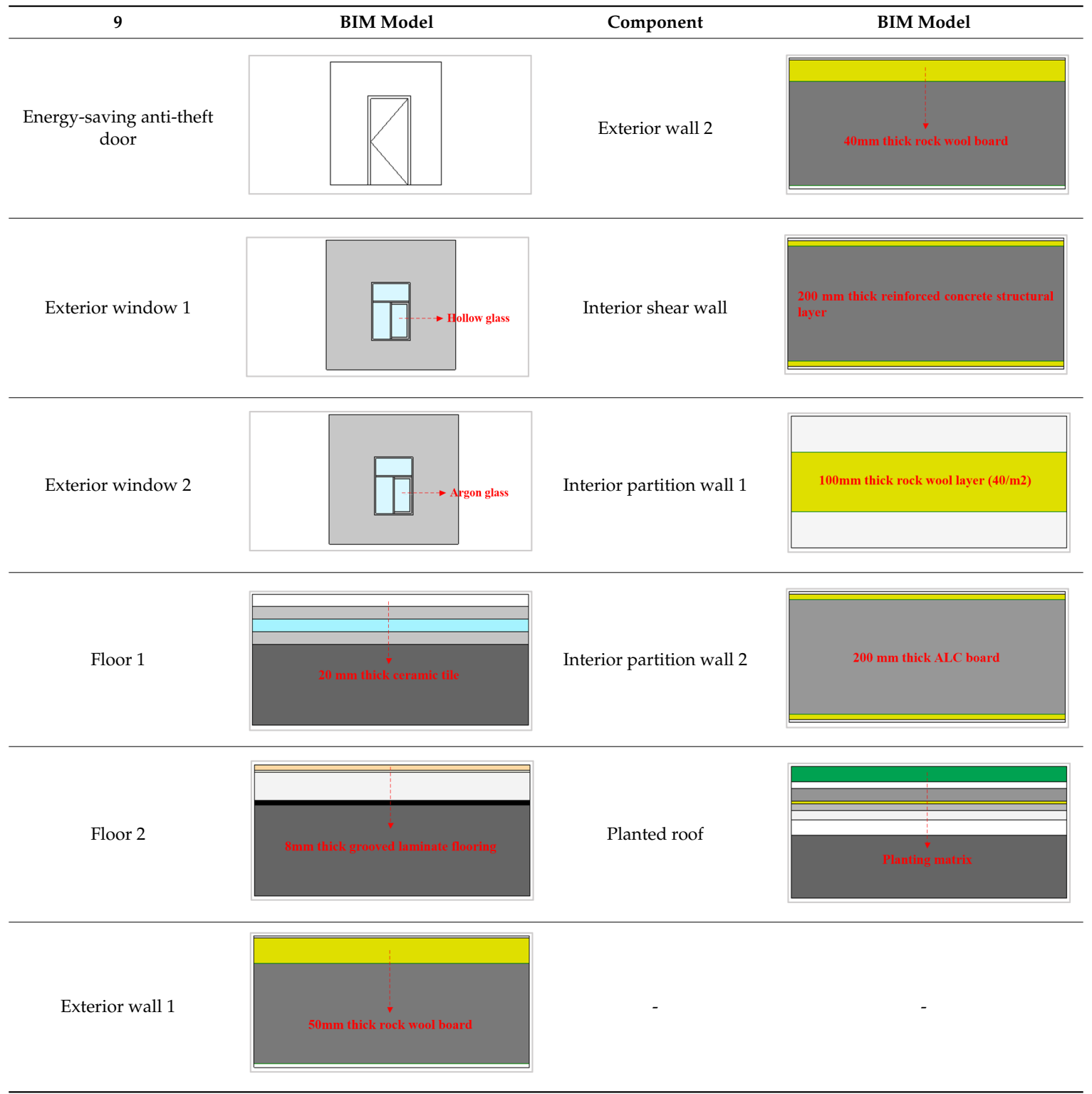

Note: A material annotation in BIM model is used to distinguish different components.

\subsection{Feasible Envelope Schemes for the Project Case}

A feasible envelope scheme refers to a scheme formed by randomly combining the available components according to certain rules. For the envelope components with two options, one needs to be randomly selected from the two options. According to the multiplication principle of permutation and combination, there are a total of 16 combinations for these components, which corresponds to 16 kinds of envelope schemes. Their detailed information is shown in Table 5. The 16 kinds of envelope schemes are simulated by PKPM-Energy one by one in advance. The simulation results show that each indicator of 16 designed buildings meet the "Design standard of thermo-environment and energy conservation for residential buildings in Jiangsu province" (DGJ32/J71-2014). Hence, the 16 kinds of envelope schemes are all up to the standard in terms of energy saving, and are eligible to participate in the subsequent optimization process. 
Table 5. 16 kinds of envelope schemes.

\begin{tabular}{|c|c|c|c|c|c|c|c|c|c|c|c|c|c|c|c|c|c|}
\hline \multicolumn{2}{|c|}{ Code of Envelope Schemes } & 1 & 2 & 3 & 4 & 5 & 6 & 7 & 8 & 9 & 10 & 11 & 12 & 13 & 14 & 15 & 16 \\
\hline $\begin{array}{l}\text { Doors and } \\
\text { windows }\end{array}$ & $\begin{array}{l}\text { Energy-saving anti-theft door } \\
\text { Exterior window } 1 \\
\text { Exterior window } 2\end{array}$ & $\begin{array}{l}\sqrt{ } \\
\sqrt{ }\end{array}$ & $\begin{array}{l}\sqrt{ } \\
\sqrt{ }\end{array}$ & $\begin{array}{l}\sqrt{ } \\
\sqrt{ }\end{array}$ & $\begin{array}{l}\sqrt{ } \\
\sqrt{ }\end{array}$ & $\begin{array}{l}\sqrt{ } \\
\sqrt{ }\end{array}$ & $\begin{array}{l}\sqrt{ } \\
\sqrt{ }\end{array}$ & $\sqrt{ }$ & $\begin{array}{l}\sqrt{ } \\
\sqrt{ }\end{array}$ & $\begin{array}{l}\sqrt{ } \\
\sqrt{ }\end{array}$ & $\begin{array}{l}\sqrt{ } \\
\sqrt{ }\end{array}$ & $\begin{array}{l}\sqrt{ } \\
\sqrt{ }\end{array}$ & $\begin{array}{l}\sqrt{ } \\
\sqrt{ }\end{array}$ & $\begin{array}{l}\sqrt{ } \\
\sqrt{ }\end{array}$ & $\begin{array}{l}\sqrt{ } \\
\sqrt{ }\end{array}$ & $\begin{array}{l}\sqrt{ } \\
\sqrt{ }\end{array}$ & $\sqrt{ }$ \\
\hline Floors & $\begin{array}{l}\text { Floor } 1 \\
\text { Floor } 2\end{array}$ & $\sqrt{ }$ & $\sqrt{ }$ & $\sqrt{ }$ & $\sqrt{ }$ & $\sqrt{ }$ & $\sqrt{ }$ & 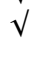 & $\sqrt{ }$ & $\sqrt{ }$ & $\sqrt{ }$ & $\sqrt{ }$ & $\sqrt{ }$ & $\sqrt{ }$ & $\sqrt{ }$ & $\sqrt{ }$ & $\sqrt{ }$ \\
\hline $\begin{array}{c}\text { Exterior } \\
\text { walls }\end{array}$ & $\begin{array}{l}\text { Exterior wall } 1 \\
\text { Exterior wall } 2\end{array}$ & $\sqrt{ }$ & $\sqrt{ }$ & $\sqrt{ }$ & $\sqrt{ }$ & $\sqrt{ }$ & $\sqrt{ }$ & $\sqrt{ }$ & $\sqrt{ }$ & $\sqrt{ }$ & $\sqrt{ }$ & $\sqrt{ }$ & $\sqrt{ }$ & $\sqrt{ }$ & $\sqrt{ }$ & $\sqrt{ }$ & $\sqrt{ }$ \\
\hline $\begin{array}{l}\text { Interior } \\
\text { walls }\end{array}$ & $\begin{array}{c}\text { Interior shear wall } \\
\text { Interior partition wall } 1 \\
\text { Interior partition wall } 2\end{array}$ & $\begin{array}{l}\sqrt{ } \\
\sqrt{ }\end{array}$ & $\begin{array}{l}\sqrt{ } \\
\sqrt{ }\end{array}$ & $\begin{array}{l}\sqrt{ } \\
\sqrt{ }\end{array}$ & $\begin{array}{l}\sqrt{ } \\
\sqrt{ }\end{array}$ & $\sqrt{ }$ & $\begin{array}{l}\sqrt{ } \\
\sqrt{ }\end{array}$ & $\begin{array}{l}\sqrt{ } \\
\sqrt{ }\end{array}$ & $\sqrt{ }$ & $\begin{array}{l}\sqrt{ } \\
\sqrt{ }\end{array}$ & $\sqrt{ }$ & $\sqrt{ }$ & $\begin{array}{l}\sqrt{ } \\
\sqrt{ }\end{array}$ & $\sqrt{ }$ & $\sqrt{ }$ & $\sqrt{ }$ & $\sqrt{ }$ \\
\hline Roofs & Planted roof & $\sqrt{ }$ & $\sqrt{ }$ & $\sqrt{ }$ & $\sqrt{ }$ & $\sqrt{ }$ & $\sqrt{ }$ & $\sqrt{ }$ & $\sqrt{ }$ & $\sqrt{ }$ & $\sqrt{ }$ & $\sqrt{ }$ & $\sqrt{ }$ & $\sqrt{ }$ & $\sqrt{ }$ & $\sqrt{ }$ & $\sqrt{ }$ \\
\hline
\end{tabular}

\subsection{Results Analysis and Discussions}

Green building evaluation is a requirement of this project. There are two kinds of energy-saving scores in the "Assessment standard for green building" (GB/T 50378-2019) in China: One kind is to score by comparing the thermal performance of envelopes with the current national building energy-saving design standard; and the other kind is to score by calculating the percentage of HVAC load reduction. The latter which is more widely used is selected here for research. Take the calculation of the envelope scheme 1 as an example. The component combination in the envelope scheme 1 is "energy-saving anti-theft door + exterior window $1+$ floor $1+$ exterior wall $1+$ inner shear wall + inner partition wall $1+$ planted roof". PKPM-Energy software is adopted to simulate the energy for the designed building corresponding to the envelope scheme 1. Figure 3 shows the monthly cooling and heating load comparison under envelope scheme 1. The value from 1 to 12 in Figure 3 corresponds to the months from January to December, respectively.

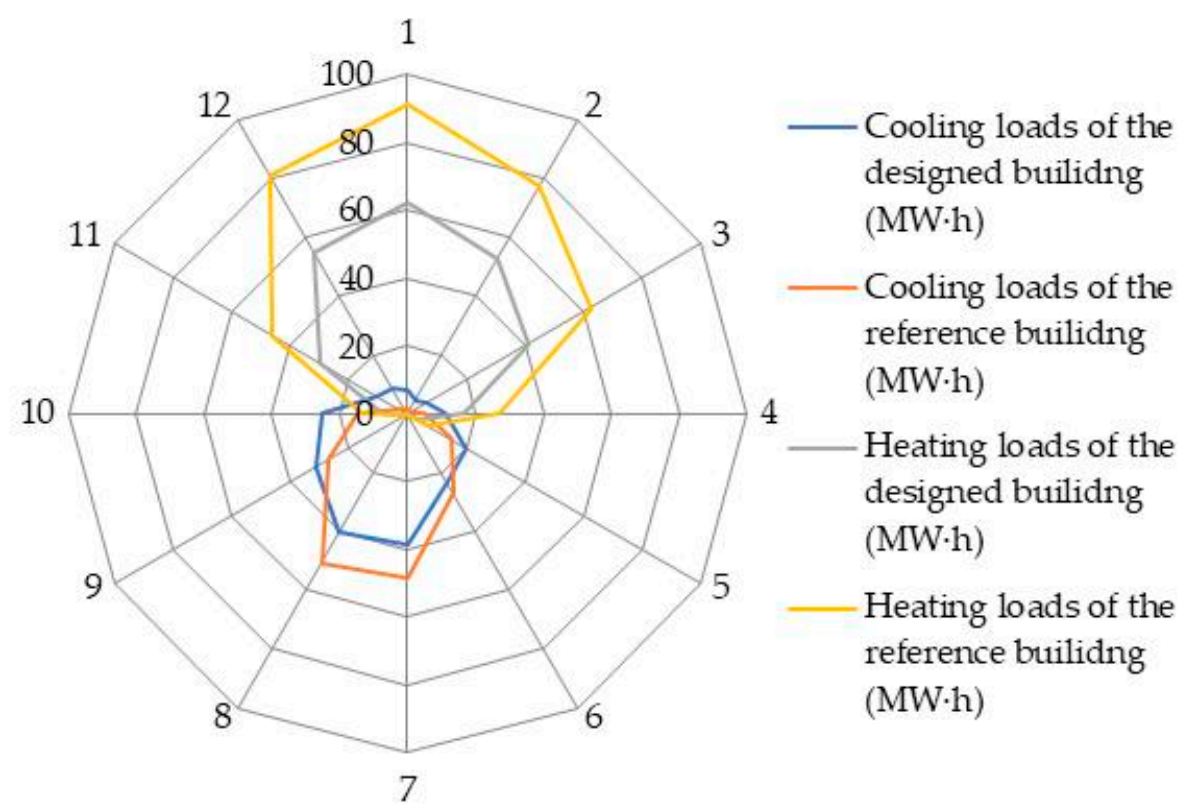

Figure 3. Monthly cooling and heating load comparison under the envelope scheme 1.

The results from PKPM-Energy software also provide the annual cumulative load statistics of HVAC system, as shown in Figure 4. The difference between the cumulative annual heating consumption and the cumulative annual cooling consumption is $107.87 \mathrm{MW} \cdot \mathrm{h}$. In the "Standard for Green Performance Calculation of Civil Engineering" (JGJ/T449-2018), the conversion weight of comprehensive efficiency for heating system is 1.80 , and the conversion weight of comprehensive efficiency for cooling system is 2.80 . Hence, the energy saving of this designed building is $66.45 \mathrm{MW} \cdot \mathrm{h}$. 
Its energy-saving rate is $22.40 \%$. According to the "Assessment standard for green building" (GB/T 50378-2019), the scoring rules for green buildings in terms of energy saving are as follows: $5=$ "energy-saving rate $<10 \%$ ", $10=$ "10\% $\leq$ energy-saving rate $<15 \%$ ", and $15=$ "energy-saving rate $\geq$ $15 \%$ ". Hence, the assessment score of the designed building corresponding to envelope scheme 1 is 15 .

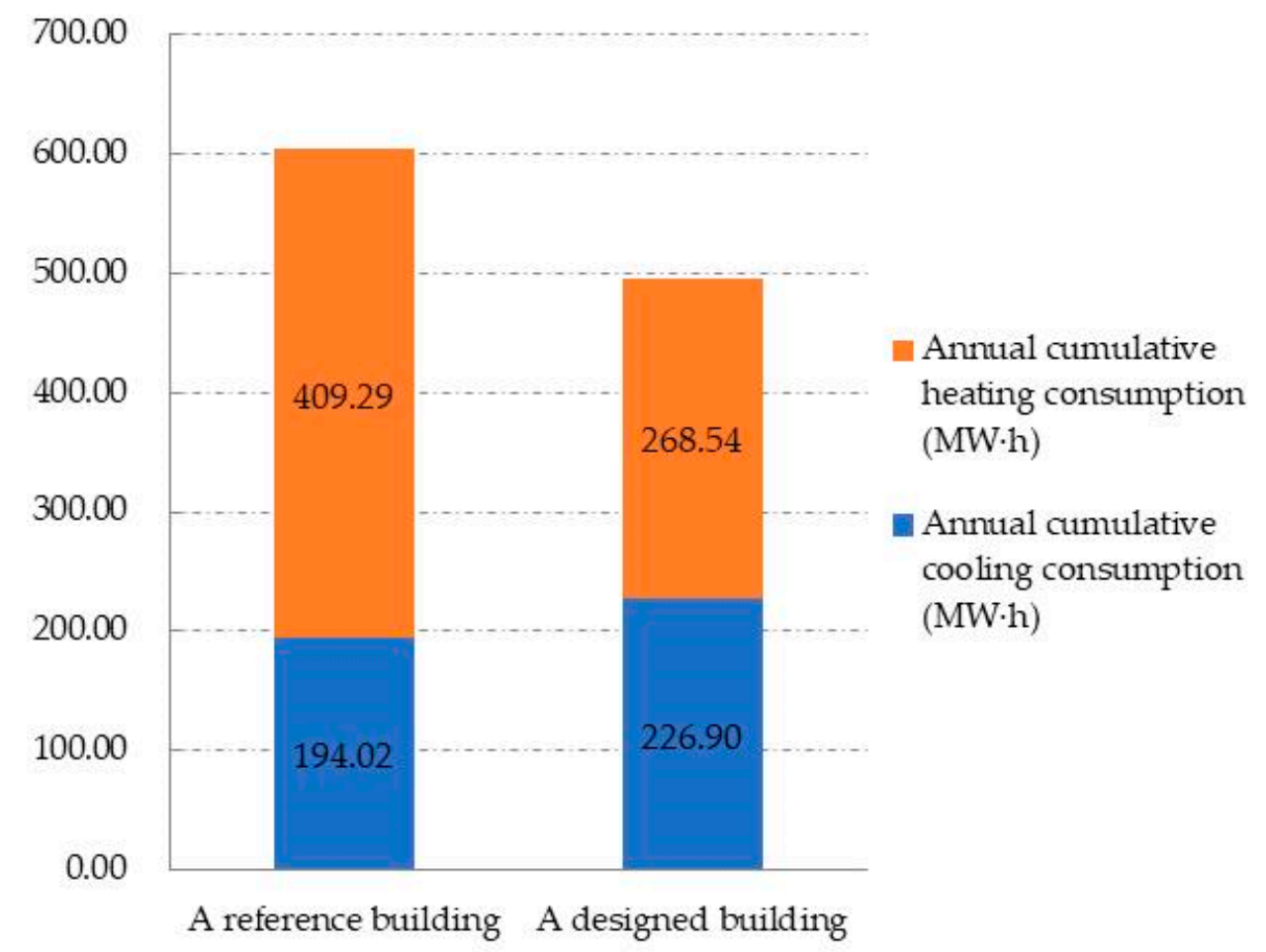

Figure 4. Annual cumulative load statistics of HVAC (heating, ventilation, and air-conditioning) system under the envelope scheme 1.

The full life cycle cost includes the total construction cost, operation cost, and demolition cost. The total construction cost of the envelope scheme 1 is calculated by multiplying the quantity of each envelope component and its comprehensive unit price (excluding the cost of reinforced concrete). The operation cost is converted to the present value based on the annual power consumption of HAVC system. The demolition cost is $1 \%$ of the total construction cost, and is also converted to the present value. After consulting the local electricity price information, the electricity price takes 0.55 yuan/ $\mathrm{KW} \cdot \mathrm{h}$. The discount rate is $8 \%$. Hence, the calculation process of the full life cycle cost and value of envelope scheme 1 is as follows:

$$
\begin{aligned}
C & =C_{1}+C_{2}(P / A, i, n)+C_{3}(P / F, i, n) \\
& =406.9693197+495.44 \times 1000 \times 0.55 \times 12.2335 \div 10000+406.9693197 \times 0.01 \times 0.0213 \\
& \approx 740.4091(\text { ten thousand yuan }) \\
V & =\frac{F}{C}=\frac{E_{s}}{C}=66.4515873 \div 740.4090924 \approx 8.97 \times 10^{-2}(M W \cdot h / \text { ten thousand yuan }) .
\end{aligned}
$$

In the same way, the life cycle cost, energy-saving, energy-saving rate, value, and scores of the envelope schemes $2 \sim 16$ are calculated. All calculation results are shown in Table 6 and Figure 5 after sorting out and summarizing. Table 6 only shows the assessment scores for 16 designed buildings in terms of energy saving. The energy-saving rate is the bridge between Table 6 and Figure 5. In order to facilitate the discovery of the relationship between the changes of the life cycle cost, energy-saving, and value, the 16 schemes in Figure 5 are arranged in ascending order according to the energy-saving (or energy-saving rate). 
Table 6. Assessment scores for 16 designed buildings in terms of energy saving.

\begin{tabular}{cccccc}
\hline Scheme & Energy-Saving Rate (\%) & Scores & Scheme & Energy-Saving Rate (\%) & Scores \\
\hline 1 & 22.40 & 15 & 9 & 14.88 & 10 \\
2 & 26.99 & 15 & 10 & 22.40 & 15 \\
3 & 22.40 & 15 & 11 & 14.88 & 10 \\
4 & 14.88 & 10 & 12 & 19.50 & 15 \\
5 & 22.40 & 15 & 13 & 26.99 & 15 \\
6 & 26.99 & 15 & 14 & 19.50 & 15 \\
7 & 19.50 & 15 & 15 & 14.88 & 10 \\
8 & 26.99 & 15 & 16 & 19.50 & 15 \\
\hline
\end{tabular}

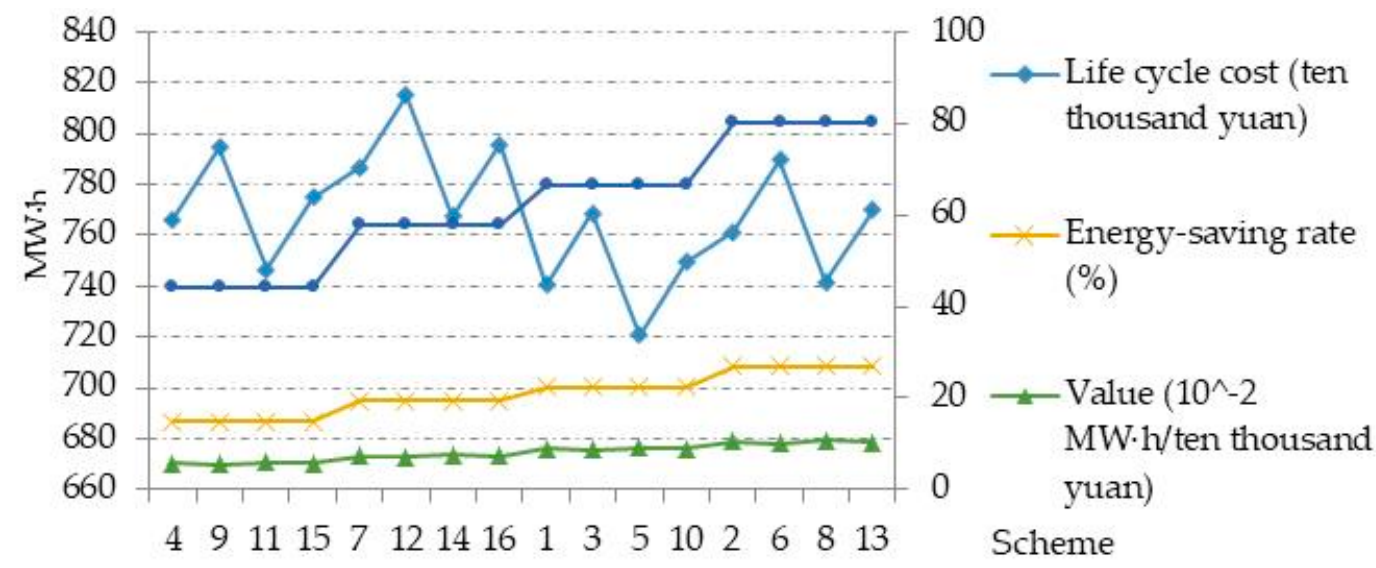

Figure 5. Life cycle cost, energy-saving, energy-saving rate, and value of each scheme.

The in-depth analysis regarding Table 6 is as follows. The assessment of designed buildings corresponding to the 16 envelope schemes in terms of energy conservation is not lower than the second level of the scoring rules for green buildings. Hence, the 16 envelope schemes meet the requirements of green buildings in terms of energy-saving assessment. An important finding is that only changing the materials of envelope components has a significant adjustment effect on building energy consumption under the same building orientation, area ratio of window to wall, and geometric size of components. The mechanism of energy saving is the interaction between the local climate and the thermal parameters of envelope components. Therefore, when the other conditions of a building cannot be changed, the building energy saving can be achieved by changing the thermal insulation materials of envelope components.

The in-depth analysis regarding Figure 5 is as follows. Only changing the thermal insulation materials of building envelopes, the corresponding value generally rises with the increase of energy-saving rate. However, the corresponding life cycle cost is irregular with the increase of energy-saving rate. This significant and valuable finding shows that it is not necessary to increase the life-cycle cost of a green building to achieve a higher energy-saving rate. Meanwhile, the findings also suggest that optimizing the design of building envelope is indispensable to improve the utility or value of a building. From the perspective of the life cycle cost, the combination scheme 5 is optimal, which corresponds to the lowest life cycle cost of 720.89 ten thousand yuan. From the perspective of energy saving, the combination scheme 2, 6, 8, and 13 is optimal, which corresponds to the highest energy-saving rate of $26.99 \%$. The method established by this paper comprehensively considers life cycle cost and energy saving to search for the optimal scheme from the perspective of value engineering. From the perspective of value, the optimal scheme is the combination scheme 8 "energy-saving and anti-theft door + exterior window $2+$ floor $1+$ exterior wall $1+$ inner shear wall + inner partition wall $2+$ planted roof". Its corresponding optimal value is $10.80 \times 10^{-2} \mathrm{MW} \cdot \mathrm{h} / \mathrm{ten}$ thousand yuan. From the above analysis, different objectives (or perspectives) correspond to different optimal schemes, and 
there is no correlation between the life-cycle cost and energy-saving rate. Hence, a comprehensive consideration of life cycle cost and energy saving becomes crucial to obtain more scientific, reliable, and realistic schemes.

\section{Conclusions and Future Work}

It is often difficult to balance the energy saving and economy of green buildings. The optimization of green building envelopes is recognized as one of the breakthrough points. In order to optimize green building envelopes from the perspective of both energy saving and life cycle cost, this study establishes an optimization method for green building envelope based on BIM-VE. Compared with existing studies, this new method is not limited to the single perspective of life cycle cost or energy saving, but adopts the value engineering (VE) to unify the energy-saving objective and cost objective. A lot of implementation work is completed in the BIM platform. The method includes four main models, namely a BIM model for architecture, a life cycle cost analysis model, energy-saving analysis model, and a value analysis model. In the BIM model for architecture, BIM technology is used to draw a three-dimensional architecture model for green buildings, which is regarded as the basis of other three models. In the life cycle cost analysis model for green building envelopes, a mathematical formula $(C)$ is proposed to calculate the life cycle cost of each envelope scheme. In the energy-saving analysis model for green building envelopes, a mathematical formula $(\mathrm{F})$ is proposed to calculate the energy saving of each envelope scheme. The output of other three models is the input of the value analysis model. In the value analysis model for green building envelopes, a mathematical formula (V $=\mathrm{F} / \mathrm{C}$ ) is proposed to calculate the value of each envelope scheme.

A prefabricated project case is used to simulate and test the proposed method. According to the "Assessment standard for green building" (GB/T 50378-2019), the designed buildings corresponding to the 16 envelope schemes meet the requirements of green buildings in terms of energy saving. The optimal envelope schemes respectively solved by life cycle cost, energy saving, and value are different. From the perspective of value, the optimal scheme is the "energy-saving and anti-theft door + exterior window $2+$ floor $1+$ exterior wall $1+$ inner shear wall + inner partition wall $2+$ planted roof" with the value $10.80 \times 10^{-2} \mathrm{MW} \cdot \mathrm{h} / \mathrm{ten}$ thousand yuan. Hence, the effectiveness of the new established method is verified. A significant finding is that the value generally rises with the increase of energy-saving rate while the life cycle cost is irregular with the increase of energy-saving rate. The finding tells people that increasing the life-cycle cost is not a sufficient condition for achieving higher energy saving of a green building. This special phenomenon may be because the high cost of components in an envelope is not just used for the energy-saving property. This finding also shows that the new method comprehensively considering life cycle cost and energy saving is more scientific and reasonable than those only considering one of the life cycle cost and energy saving.

The new method established by this study provides a new idea of optimizing the building envelope from the perspective of both life cycle cost and energy saving. It introduces value engineering technology into architectural design to further expand the current boundary of building energy-saving theory. The findings and suggestions will provide a valuable reference and guidance for architectural design departments to optimize the envelope from the perspective of both energy saving and life cycle cost. However, life cycle cost will be affected by time and market. Future continuous research is necessary to perfect the theory established in this paper.

Author Contributions: Conceptualization, Z.Y., J.Z., and Y.Z.; methodology, Z.Y., J.Z., Y.Q., and Y.Z.; software, Y.Z., D.L., and H.Z.; validation, Z.Y. and Y.Z.; formal analysis, Z.Y.,Y.Z., D.L., and H.Z.; investigation, Y.Z.; resources, J.Z.; data curation, Z.Y. and Y.Z.; writing-original draft preparation, Z.Y. and Y.Z.; writing-review and editing, Y.Q.; visualization, Z.Y.,Y.Z., D.L., and H.Z.; supervision, J.Z.; project administration, Z.Y. and J.Z.; funding acquisition, Z.Y. All authors have read and agreed to the published version of the manuscript.

Funding: This research was funded by the Fundamental Research Funds for the Central Universities (Project No. 2020QN73), the Humanities and Social Sciences Foundation of China's Education Ministry (Project No. 19YJAZH122), and the National Natural Science Foundation of China (Project No. 51878026). 
Acknowledgments: The authors would like to express our sincere thanks to Beijing Glory PKPM Technology Co., Ltd. and China Academy of Building Research for providing relevant software and guidance.

Conflicts of Interest: The authors declare no conflict of interest.

\section{Appendix A}

The parameters in the formulas and their explanations are summarized in Table A1. These parameters are arranged according to the relationship of $V=F / C$. The parameter $C$ includes $C_{1}, C_{2}$, and $C_{3}$. The parameter $F$ is represented by $E_{\mathrm{dh}}, E_{\mathrm{dc}}, E_{\mathrm{rh}}$, and $E_{\mathrm{rc}}$.

Table A1. Parameters in the formulas and their explanations.

\begin{tabular}{cl}
\hline Symbol & \multicolumn{1}{c}{ Explanation } \\
\hline$V$ & The value of an envelope scheme \\
$C$ & The life cycle cost of an envelope scheme \\
$C_{1}$ & The construction cost of an envelope \\
$C_{2}$ & The annual operation cost of an envelope \\
$C_{3}$ & The demolition cost of an envelope \\
$F$ & The function of an envelope scheme \\
$E_{\mathrm{dh}}$ & The annual heating energy consumption of a designed building \\
$E_{\mathrm{dc}}$ & The annual cooling energy consumption of a designed building \\
$E_{\mathrm{rh}}$ & The annual heating energy consumption of a referenced building \\
$E_{\mathrm{rc}}$ & The annual cooling energy consumption of a referenced building \\
\hline
\end{tabular}

Information regarding the main components and their alternatives is shown in Table A2. The material information, thermal parameters and comprehensive unit price of building envelope components refers to a local quota and a building material inquiry platform. The price of energy-saving anti-theft door is taken from the "Quota of Construction and Decoration Engineering of Jiangsu Province" (2014). The material prices of other components come from the data on the authoritative website (www.gldjc.com) from June 2019 to April 2020.

Table A2. Information regarding the main components and their alternatives.

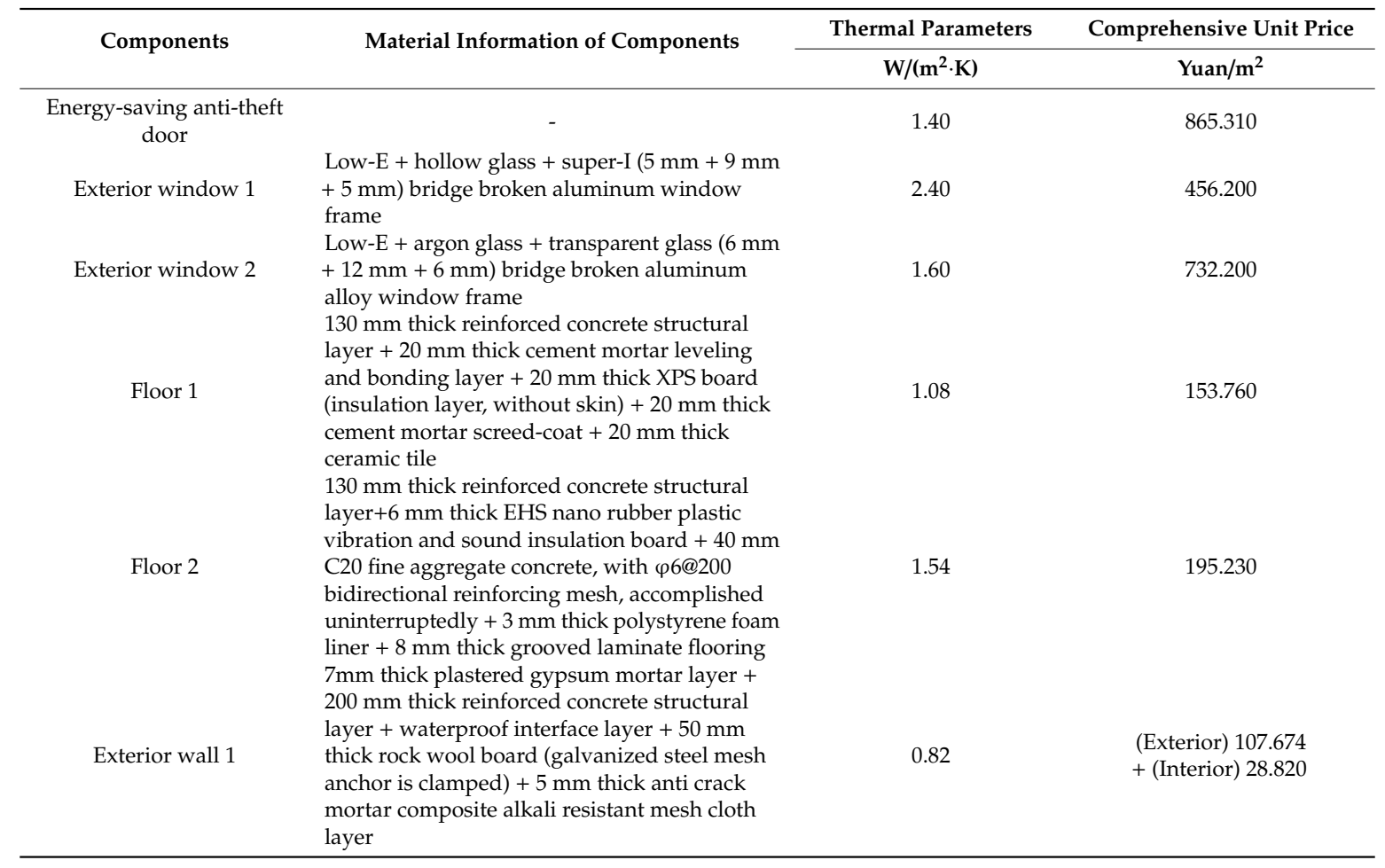


Table A2. Cont.

\begin{tabular}{|c|c|c|c|}
\hline \multirow{2}{*}{ Components } & \multirow{2}{*}{ Material Information of Components } & Thermal Parameters & Comprehensive Unit Price \\
\hline & & $\mathrm{W} /\left(\mathrm{m}^{2} \cdot \mathrm{K}\right)$ & Yuan $/ \mathrm{m}^{2}$ \\
\hline Exterior wall 2 & $\begin{array}{l}7 \mathrm{~mm} \text { thick plastered gypsum mortar layer }+ \\
200 \mathrm{~mm} \text { thick reinforced concrete structural } \\
\text { layer }+ \text { waterproof interface layer }+40 \mathrm{~mm} \\
\text { thick rock wool board (galvanized steel mesh } \\
\text { anchor is clamped) }+5 \mathrm{~mm} \text { thick anti crack } \\
\text { mortar composite alkali resistant mesh cloth } \\
\text { layer }\end{array}$ & 0.97 & $\begin{array}{l}\text { (Exterior) } 103.674 \\
+ \text { (Interior) } 28.820\end{array}$ \\
\hline Interior shear wall & $\begin{array}{l}5 \mathrm{~mm} \text { thick anti cracking and moisture-proof } \\
\text { mortar layer }+10 \mathrm{~mm} \text { thick rock wool board } \\
\text { (galvanized steel mesh anchor is clamped) }+200 \\
\mathrm{~mm} \text { thick reinforced concrete structural } \\
\text { layer+10mm thick rock wool board (galvanized } \\
\text { steel mesh anchor is clamped) }+5 \mathrm{~mm} \text { thick anti } \\
\text { cracking and moisture-proof mortar layer }\end{array}$ & 1.09 & 28.000 \\
\hline Interior partition wall 1 & $\begin{array}{l}60 \mathrm{~mm} \text { thick GRC perforated strip }+100 \mathrm{~mm} \\
\text { thick rock wool layer }(40 / \mathrm{m} 2)+60 \mathrm{~mm} \text { thick } \\
\text { GRC perforated strip }\end{array}$ & 0.37 & 222.655 \\
\hline Interior partition wall 2 & $\begin{array}{l}5 \mathrm{~mm} \text { thick anti cracking and moisture-proof } \\
\text { mortar layer }+10 \mathrm{~mm} \text { thick rock wool board } \\
\text { (galvanized steel mesh anchor is clamped) }+ \\
200 \mathrm{~mm} \text { thick ALC board }+10 \mathrm{~mm} \text { thick rock } \\
\text { wool board (galvanized steel mesh anchor is } \\
\text { clamped) }+5 \mathrm{~mm} \text { thick anti cracking and } \\
\text { moisture-proof mortar layer }\end{array}$ & 0.66 & 178.215 \\
\hline Planted roof & $\begin{array}{l}\text { Main structural layer }+50 \text { mm thick xps } \\
\text { insulation board }+30 \text { mm thick } 2 \% \text { slope } \\
\text { formation made of lightweight aggregate } \\
\text { concrete }+20 \mathrm{~mm} \text { thick } 1: 3 \text { cement to mortar } \\
\text { screed-coat }+ \text { waterproof layer }+10 \text { mm thick } \\
\text { isolation layer made of low strength mortar }+ \\
40 \mathrm{~mm} \text { thick rigid waterproof } \mathrm{C} 20 \text { concrete } \\
\text { layer }+20 \mathrm{~mm} \text { drainage layer made of thick } \\
\text { high strength plastic }+ \text { geotextile filter layer }+ \\
\text { planting matrix }\end{array}$ & 0.54 & 218.769 \\
\hline
\end{tabular}

\section{References}

1. Lu, S.L.; Liu, Y.; Sun, Y.C.; Yin, S.; Jiang, X.Y. Indoor thermal environmental evaluation of Chinese green building based on new index OTCP and subjective satisfaction. J. Clean. Prod. 2019, 240, 118151. [CrossRef]

2. Wang, P.; Gong, G.; Cai, L.; Xie, H.; Gong, S. Investigation of the ratio of exergy consumption to energy consumption for building energy efficiency. Int. J. Green Energy 2018, 15, 681-691. [CrossRef]

3. Wang, Z.; Srinivasan, R.S. A review of artificial intelligence based building energy use prediction: Contrasting the capabilities of single and ensemble prediction models. Renew. Sustain. Energy Rev. 2017, 75, 796-808. [CrossRef]

4. Duc-Hoc, T.; Duc-Long, L.; Chou, J.S. Nature-inspired metaheuristic ensemble model for forecasting energy consumption in residential buildings. Energy 2020, 191, 116552. [CrossRef]

5. Xu, G.; Wang, W. China's energy consumption in construction and building sectors: An outlook to 2100. Energy 2020, 195, 117045. [CrossRef]

6. Azizi, N.S.M.; Wilkinson, S.; Fassman, E. Strategies for improving energy saving behaviour in commercial buildings in Malaysia. Eng. Constr. Architect. Manag. 2015, 22, 73-90. [CrossRef]

7. Ding, Z.K.; Li, Z.J.; Fan, C. Building energy savings: Analysis of research trends based on text mining. Automat. Constr. 2018, 96, 398-410. [CrossRef]

8. Ustaoglu, A.; Kurtoglu, K.; Gencel, O.; Kocyigit, F. Impact of a low thermal conductive lightweight concrete in building: Energy and fuel performance evaluation for different climate region. J. Environ. Manag. 2020, 268, 110732. [CrossRef]

9. Zhang, Y.; Wang, H.; Gao, W.; Wang, F.; Zhou, N.; Kammen, D.M.; Ying, X. A survey of the status and challenges of green building development in various countries. Sustainability 2019, 11, 5385. [CrossRef]

10. Wu, Z.Z.; Jiang, M.Y.; Cai, Y.Z.; Wang, H.; Li, S.H. What hinders the development of green building? An investigation of China. Int. J. Environ. Res. Public Health 2019, 16, 3140. [CrossRef] 
11. Huang, Z.Y.; Yuan, H.P.; Shen, L.Y. Contribution of promoting the green residence assessment scheme to energy saving. Energy Policy 2012, 51, 374-381. [CrossRef]

12. Raji, B.; Tenpierik, M.J.; van den Dobbelsteen, A. The impact of greening systems on building energy performance: A literature review. Renew. Sustain. Energy Rev. 2015, 45, 610-623. [CrossRef]

13. Zhang, Y.; Kang, J.; Jin, H. A review of green building development in China from the perspective of energy saving. Energies 2018, 11, 334. [CrossRef]

14. Huang, M.Q.; Wang, B. Evaluating green performance of building products based on gray relational analysis and analytic hierarchy process. Environ. Progr. Sustain. Energy 2014, 33, 1389-1395. [CrossRef]

15. Lu, S.L.; Fan, M.C.; Zhao, Y.Q. A system to pre-evaluate the suitability of energy-saving technology for green buildings. Sustainability 2018, 10, 3777. [CrossRef]

16. Dimassi, N.; Dehmani, L. Performance comparison between an improved and a classical Trombe wall: An experimental study. J. Build. Phys. 2017, 40, 372-395. [CrossRef]

17. Du, X.; Jia, B. Discussion on applying trombe wall technology for wall conservation and energy saving in modern historic buildings. Int. J. Archit. Heritage 2019, 13, 537-548. [CrossRef]

18. Kim, K.; Yu, J. A process to divide curved walls in ifc-bim into segmented straight walls for building energy analysis. J. Civil Eng. Manag. 2016, 22, 333-345. [CrossRef]

19. Omrany, H.; Ghaffarianhoseini, A.; Ghaffarianhoseini, A.; Raahemifar, K.; Tookey, J. Application of passive wall systems for improving the energy efficiency in buildings: A comprehensive review. Renew. Sustain. Energy Rev. 2016, 62, 1252-1269. [CrossRef]

20. Sim, J.; Sim, J. The effect of external walls on energy performance of a Korean traditional building. Sustain. Cities Soc. 2016, 24, 10-19. [CrossRef]

21. Coma, J.; Perez, G.; Castell, A.; Sole, C.; Cabeza, L.F. Green roofs as passive system for energy savings in buildings during the cooling period: Use of rubber crumbs as drainage layer. Energy Efficiency 2014, 7, 841-849. [CrossRef]

22. Kokogiannakis, G.; Darkwa, J. Support for the integration of green roof constructions within Chinese building energy performance policies. Energy 2014, 65, 71-79. [CrossRef]

23. Moody, S.S.; Sailor, D.J. Development and application of a building energy performance metric for green roof systems. Energy Build. 2013, 60, 262-269. [CrossRef]

24. Sailor, D.J.; Elley, T.B.; Gibson, M. Exploring the building energy impacts of green roof design decisions-A modeling study of buildings in four distinct climates. J. Build. Phys. 2012, 35, 372-391. [CrossRef]

25. Coma, J.; Chafer, M.; Perez, G.; Cabeza, L.F. How internal heat loads of buildings affect the effectiveness of vertical greenery systems? An experimental study. Renew. Energy 2020, 151, 919-930. [CrossRef]

26. Gonzalez-Mendez, B.; Chavez-Garcia, E. Re-thinking the Technosol design for greenery systems: Challenges for the provision of ecosystem services in semiarid and arid cities. J. Arid Environ. 2020, 179, 104191. [CrossRef]

27. Hao, X.; Xing, Q.; Long, P.; Lin, Y.; Hu, J.; Tan, H. Influence of vertical greenery systems and green roofs on the indoor operative temperature of air-conditioned rooms. J. Build. Eng. 2020, 31, 101373. [CrossRef]

28. Pan, L.; Wei, S.; Lai, P.Y.; Chu, L.M. Effect of plant traits and substrate moisture on the thermal performance of different plant species in vertical greenery systems. Build. Environ. 2020, 175, 106815. [CrossRef]

29. Zheng, X.; Dai, T.; Tang, M. An experimental study of vertical greenery systems for window shading for energy saving in summer. J. Clean. Prod. 2020, 259, 120708. [CrossRef]

30. Lin, Y.H.; Tsai, K.T.; Lin, M.D.; Yang, M.D. Design optimization of office building envelope configurations for energy conservation. Appl. Energy 2016, 171, 336-346. [CrossRef]

31. Sadineni, S.B.; Madala, S.; Boehm, R.F. Passive building energy savings: A review of building envelope components. Renew. Sustain. Energy Rev. 2011, 15, 3617-3631. [CrossRef]

32. Setiawan, A.F.; Huang, T.L.; Tzeng, C.T.; Lai, C.M. The effects of envelope design alternatives on the energy consumption of residential houses in Indonesia. Energies 2015, 8, 2788-2802. [CrossRef]

33. Svetozarevic, B.; Begle, M.; Jayathissa, P.; Caranovic, S.; Shepherd, R.F.; Nagy, Z.; Schlueter, A. Dynamic photovoltaic building envelopes for adaptive energy and comfort management. Nature Energy 2019, 4, 671-682. [CrossRef]

34. Lu, S.L.; Wang, R.; Zheng, S.Q. Passive optimization design based on particle swarm optimization in rural buildings of the hot summer and warm winter zone of China. Sustainability 2017, 9, 2288. [CrossRef] 
35. Lu, S.L.; Wang, Z.C.; Zhang, T.S. Quantitative analysis and multi-index evaluation of the green building envelope performance in the cold area of China. Sustainability 2020, 12, 437. [CrossRef]

36. Xie, X.; Lu, Y.; Gou, Z. Green building pro-environment behaviors: Are green users also green buyers? Sustainability 2017, 9, 1703. [CrossRef]

37. Chiradeja, P.; Ngaopitakkul, A. Energy and economic analysis of tropical building envelope material in compliance with thailand's building energy code. Sustainability 2019, 11, 6872. [CrossRef]

38. Iwaro, J.; Mwasha, A.; Narinesingh, P. Validation of integrated performance model for sustainable envelope performance assessment and design. Int. J. Low-Carbon Technol. 2017, 12, 189-207. [CrossRef]

39. Baglivo, C.; Congedo, P.M.; Di Cataldo, M.; Coluccia, L.D.; D'Agostino, D. Envelope design optimization by thermal modelling of a building in a warm climate. Energies 2017, 10, 1808. [CrossRef]

40. Chung, B.Y.; Syachrani, S.; Jeong, H.S.; Kwak, Y.H. Applying process simulation technique to value engineering model: A case study of hospital building project. IEEE Trans. Eng. Manag. 2009, 56, 549-559. [CrossRef]

41. Pučko, Z.; Maučec, D.; Šuman, N. Energy and Cost Analysis of Building Envelope Components Using BIM: A Systematic Approach. Energies 2020, 13, 2643. [CrossRef]

42. Yu, M.; Robati, M.; Oldfield, P.; Wiedmann, T.; Crawford, R.; Nezhad, A.A.; Carmichael, D. The impact of value engineering on embodied greenhouse gas emissions in the built environment: A hybrid life cycle assessment. Build. Environ. 2020, 168, 106452. [CrossRef]

43. Tam, V.W.Y.; Senaratne, S.; Le, K.N.; Shen, L.Y.; Perica, J.; Illankoon, I.M.C.S. Life-cycle cost analysis of green-building implementation using timber applications. J. Clean. Prod. 2017, 147, 458-469. [CrossRef]

44. Monstvilas, E.; Banionis, K.; Stankevicius, V.; Karbauskaite, J.; Bliudzius, R. Heat gains in buildings—Limit conditions for calculating energy consumption. J. Civil Eng. Manag. 2010, 16, 439-450. [CrossRef]

45. Zhang, J.; Li, R.Y. Design and development of building energy simulation software for prefabricated cabin type of industrial building (PCES). In Proceedings of the 2018 4th International Conference on Energy Materials and Environment Engineering, Kuala Lumpur, Malaysia, 13-15 April 2018; Volume 38, p. 03019. [CrossRef]

46. Jin, X.; Qi, F.; Wu, Q.; Mu, Y.; Jia, H.; Yu, X.; Li, Z. Integrated optimal scheduling and predictive control for energy management of an urban complex considering building thermal dynamics. Int. J. Electr. Power Energy Syst. 2020, 123, 106273. [CrossRef]

47. Congedo, P.M.; Baglivo, C.; Centonze, G. Walls comparative evaluation for the thermal performance improvement of low-rise residential buildings in warm Mediterranean climate. J. Build. Eng. 2020, 28, 101059. [CrossRef]

48. Zaca, I.; D'Agostino, D.; Congedo, P.M.; Baglivo, C. Data of cost-optimality and technical solutions for high energy performance buildings in warm climate. Data Brief 2015, 4, 222-225. [CrossRef]

49. Chang, S.; Castro-Lacouture, D.; Yamagata, Y. Decision support for retrofitting building envelopes using multi-objective optimization under uncertainties. J. Build. Eng. 2020, 32, 101413. [CrossRef]

50. Natephra, W.; Yabuki, N.; Fukuda, T. Optimizing the evaluation of building envelope design for thermal performance using a BIM-based overall thermal transfer value calculation. Build. Environ. 2018, 136, 128-145. [CrossRef]

51. Arnfield, A.J. Köppen Climate Classification, Encyclopædia Britannica. Available online: https://www. britannica.com/science/Koppen-climate-classification (accessed on 22 September 2020).

52. Chen, D.; Chen, H.W. Using the Köppen classification to quantify climate variation and change: An example for 1901-2010. Environ. Dev. 2013, 6, 69-79. [CrossRef]

(C) 2020 by the authors. Licensee MDPI, Basel, Switzerland. This article is an open access article distributed under the terms and conditions of the Creative Commons Attribution (CC BY) license (http://creativecommons.org/licenses/by/4.0/). 